\title{
Is There a Private Life Free from Forms of Social Control?
}

\author{
L'ubica SaKtorová*
}

\begin{abstract}
The present work focuses on the analytical examination of privacy and private life through the concept of formal and informal forms of social control. While the formal social control is expressed through the national and international legal rules, standards and statutes, the analysis will be pointed to the substantive list of human rights guaranteeing the spheres of privacy. The second part will examine the subject in context of informal form of social control, thus determining the respect to privacy in customary culture, moral codes, and contemporary surveillance mechanisms. The private life is guaranteed and safeguarded by the high number of legal rules. However, it is up to one 's own conduct to secure it.
\end{abstract}

Key words: privacy, private life, social control, human rights, freedom

\section{INTRODUCTION}

'Privacy' is generally understood as part of individual existence, free from public attention, in which one is not disturbed or observed by other people. 'Private life' consequently derives from such definition as a wider conception related to personal, intimate, individual space. This notion can have a further division into correlating concepts such as informational, bodily, territorial privacy or the one of communication. A unified definition is hard to find as the notions of 'private life' vary differently. ${ }^{1}$ It has been a point of discussions and philosophical analysis since the ancient times of Aristotle. ${ }^{2}$ His distinction between the domestic family life and the public, professional life traced some of the first ideas about human integrity, freedom from social influence and power. Later, this concept evolved into wider anthropological, sociological, and legal debates, whereby the privacy and private life gained again a different status, importance, and stress. The revival of an idea as a legal concept came in the end of $19^{\text {th }}$ century. ${ }^{3}$ After the atrocities of the World wars, the international community agreed on the framework of human rights worth the universal protection. The aim was to provide people with guarantees that the same scenario will not be repeated, and the individual human dignity will stand in the middle of the international social interest. The Universal declaration of human rights 1948 claims the various range of rights, the very right to privacy did not remain neglected.

Contemporary society uses the term 'private life' increasingly alongside with tendencies of authorities to strengthen the system of surveillance of its citizens. This has disputably evolved as the postwar need to regulate the behaviour of individuals in order to maintain efficient, productive, motivated entity; which would be at the same time safe and peaceful. The striking elements of today's world such as terrorism, the enhancement of various criminal acts and different forms of deviances give an argument to the hands of

* Associate lecturer, Matej Bel University in Banská Bystrica, Faculty of Law. Vice-dean for the international relations and development, head of the Institute for the clinical education lubica. saktorova@umb.sk.

1 Moore (2010) 11.

2 See DeCew (2008) link 1.

3 Warren and Brandeis (1890) 193. 
competent establishments to claim that repression of such fearful threats undermining the peace and security is the priority. ${ }^{4}$ In spite of maintaining the inherent social and cultural values, the control mechanisms penetrate the lives of people.

The various aspects of privacy in context of the social networks boom are not subjects of the paper. This study will be focused on the examination of privacy and 'private life' through the concept of formal and informal forms of social control. While the formal social control is expressed through the rule of law, international standards and statutes, the analysis will be pointed to the substantive list of human rights guaranteeing the spheres of privacy and the consequent caselaw supporting the whole idea. ${ }^{5}$ The second part will examine the subject in context of informal form of social control, thus determining the respect to privacy in customary culture, moral codes, and contemporary surveillance mechanisms. This part will outline the cultural and moral basis of the perception and restriction of privacy.

\section{A 'PRIVATE LIFE' VERSUS FORMAL SOCIAL CONTROL}

The rule of law accomplishes the function to regulate the relationships within society. For an individual, the legal rules represent sort of crash barriers, which might protect, guide, or restrict the space of a safe journey. They are not everywhere but whenever someone wonders about the broadness of an empty road, the international or regional community, domestic government, or judiciary clarify the limits. Accordingly, the same crash barriers should be safeguarding the personal space of an individual. To what extent are these vice versa measures realised, is the subject of the human rights law.

Firstly, one of the international legal instruments protecting and promoting the features of private life is the 1948 Universal Declaration of Human Rights (UDHR). The Article 12 particularly protects the privacy stating:

No one should be subjected to arbitrary interference with his privacy, family, home, or correspondence, nor to attacks on his honour or reputation. Everyone has the right to the protection of the law against such interferences or attacks.

Within its Article 16, the UDHR declare the family as a natural and fundamental unit of society under protection of State, in which the people have a right to marry, to give a free consent to marriage or to start a family. The privacy is thus recognised through the family life and its protection. Most of the other international conventions and treaties determine the protection of the private life, such as 1966 International Covenant on Civil and Political Rights (ICCPR) ${ }^{6}$ or International Convention on the Protection of the Rights of All Migrant Workers and Members of Their Families (CMW). ${ }^{7}$ Furthermore, the Article 16 of the Convention of the Rights of Child explicitly establishes that "no child shall be subjected to arbitrary or unlawful interference with his or her privacy, family, home or correspondence, nor to unlawful attacks on his or her honour and reputation'.

\footnotetext{
${ }^{4}$ Goda and Ušiak (2016) 64.

5 Júda (2018) 86.

${ }^{6}$ Article 17 of ICCPR.

7 Article 14 of CMW.
} 
The UN treaty based bodies, or the Office of High Commissioner of Human Rights are provided with the mechanisms of enforcement of these rights. One is the control over the implementation of the international rules into domestic legislation through the regular state reports. Their adherence is further monitored by the non-governmental organisations and their reporting system. Another method of enforcement is an individual petition mechanism. In a case of the breach of rights, for instance, the right to privacy guaranteed by the UDHR or Conventions, the individual has a right to complain and to apply for remedy. Hence, the international standards accredit the 'private life' with the list of rights and liberties ensuring the freedom from the unauthorised interferences.

Secondly, on the regional level, African, American, Islamic and European legislation tend over individual privacy. The 1981 African Charter on Human and People's Rights does not explicitly recognise the right to privacy, although the 'family life' enjoys the protection under Article 18. The American rules are in this sense more developed and the 1969 American Convention of Human Rights (ACHR) provides people with similar concept as the UDHR. ${ }^{8}$ The right to privacy is further codified and proclaimed by the Article 5 of the 1947 American Declaration of the Rights and Duties of Man stating that:

Every person has the right to the protection of the law against abusive attacks upon his honour, his reputation, and his private and family life.

The Islamic human rights safeguard is represented by the 1990 Cairo Declaration on Human Rights in Islam, whereby the private life is protected by Article 18:

Everyone shall have the right to privacy in the conduct of his private affairs, in his home, among his family, with regard to his property and his relationships. It is not permitted to spy on him, to place him under surveillance or to besmirch his good name... A private residence is inviolable in all cases...

Islamic culture indeed declares the limits of social control in forms of surveillance and snooping is considered unlawful, the territorial privacy is guaranteed as well. The last regional entity of the human rights protection is the one built by European states. Article 8 of the 1950 European Convention for the Protection of Human Rights and Fundamental Freedoms (ECHR) ${ }^{9}$ differs from the other regional associates essentially by the legal force of judgements and the approach to enforcement. The Committee of Ministers of the Council of Europe is an organ additionally charged with the supervision over the enforcement of the judgements of European Court of Human Rights. ${ }^{10}$ Consequently the abuses of the rights related to privacy, after exhaustion of national remedies, might be sent to Strasbourg, where the authorities decide the matter and provide the appropriate remedies. The European case law contributed to the understanding of privacy in terms of valuable jurisprudence and

8 Article 11 of ACHR.

9 '(1) Everyone has the right to respect for his private and family life, his home and his correspondence. (2) There shall be no interference by a public authority with the exercise of this right except as in accordance with the law and is necessary in a democratic society in the interests of national security, public safety or the economic well-being of the country, for the prevention of disorder or crime, for the protection of health of morals, or for the protection of the rights and freedoms of others.'

10 Article 46 of ECHR, Protocol No. 11 and 14. 
commentaries. ${ }^{11}$ The European Union as key European political entity requires the State Parties to implement its primary and secondary legislation. On this level, protection of a privacy of individual evolved into several directives and recommendations, mainly related to personal data in use of technical devices. The latest one General Data Protection Regulation "GDPR" 2016/ 679 is the regulation on protection of data and other features of privacy of individuals within the European Union and the European Economic Area. The GDPR primarily aims to give control to citizens and residents of EU over the protection of their personal data and is widely considered to be the ultimate level of legal regulation of privacy. ${ }^{12}$

Thirdly, the right to privacy found the determination in the number of national legislations. On one hand, there is a pressure to incorporate such legislation from the international community in order to promote certain degree of security of person whilst on the other, there are the ethical, political and economic reasons. While the 'right to privacy' was categorized as one of the internationally recognised human rights and the development of surveillance technologies began to increase, people have started to determine their private lives as objects of mere protection. ${ }^{13}$ The lack of comprehensive legislation at the national level led to codification of human rights accordingly in United Kingdom. Human Rights Act came into force in 1998 and provided judges with an opportunity to interpret the international rules within the domestic context. Moreover, it provided the citizens with a right of remedy by domestic court in case of unregulated surveillance practices. Particularly, the UK surveillance system is scenically very rich and consequently needs more regulations in order not to collide with Article 8 of ECHR. For instance, the Regulation of Investigatory Powers Act 2000 put down controversial features inter alia the authority to issue notices requiring the disclosure of encrypted material and the consequent offence of failure to comply with such a notice. ${ }^{14}$ On the other hand, the provisions of ECHR generated the pressure on the UK government to clearly and comprehensively enact the conditions of the surveillance practices on a statutory basis. ${ }^{15}$

According to the substantial list of human rights, which has been accepted internationally and on the regional political field, there is no doubt, whether the "private

11 Smith and Grady v United Kingdom (1999) 29 EHRR 493 (the investigation and subsequent discharge of personnel from the Royal Navy on the basis of sexual orientation); $S$ and Marper $v$ The United Kingdom [2008] ECHR 1581 (holding DNA samples of individuals arrested, who are later acquitted or have the charges against them dropped is a violation of the right to privacy); Slivenko $v$ Latvia (2003) 48321/99 (deportation order of mother and daughter based on 1994 treaty requiring the withdrawal of Russian troops and their families from Latvia); Cyprus v Turkey [GC], no. 25781/94, § 175, ECHR 2001-IV para. 95 (Article 8 applies to the exclusion of displaced persons from their homes); Amman v Switzerland (2000) 30 EHRR 843 (EctHR re-emphasis the need for clear and precise rules governing covert surveillance techniques); Niemietz v Germany (1992)16 EHRR 97 ('it would be too restrictive to limit the notion to an 'inner circle' in which the individual may live his own personal life as he chooses and to exclude therefrom entirely the outside world not encompassed within that circle. Respect for private life must also comprise to a certain degree the right to establish and develop relationships with other human beings.'); $X v$ United Kingdom (App. No. 5877/72) (taking and storage of photographs of a woman taking part in demonstration is not a prima facie breach of Article 8).

12 Regulation (EU) 2016/679 of GDPR.

13 Steiner (2007).

14 Clause 53 of the Regulation of Investigatory Powers Act 2000.

15 Taylor (2008) 72. 
life' does or does not have a restricted place free from the social control. In order to create a life without unlawful interference, the authorities agreed on the set of rules governing the guarantees of personal space. On the other hand, to what extent is this establishment sufficient and acceptable depends solely on the individual expectations, experiences, and perception of their own freedom.

\section{A 'PRIVATE LIFE' VERSUS INFORMAL SOCIAL CONTROL}

The private life in context of informal social control is closely related to individuality, personal integrity and the way of their protection. While a human being is a social creature, the separation of the external influences is almost impossible. The trends and expectations of society generate the pressure on behaviour and consequently push aside the natural and private features of individual's life. The perception what is private and what is not therefore differ in terms of the level of this influence as well as the degree of personal vulnerability. To evaluate the restrictions of privacy, there are cultural, human, and other social predispositions to consider.

Firstly, domestic rules are the closest element for a human being to recognise their limits. ${ }^{16}$ The statement on Human Rights of the American Anthropological Association claims that 'man is free only when he lives as his society defines freedom. ${ }^{17}$ The social rules mirror history, culture, traditions, or customs that influence the being and the behaviour of the person. At a state level, it is most likely to identify specifically to what extent the private life of citizen would be free from the forms of social control. ${ }^{18}$ In addition, it is most likely to determine tools of privacy protection and the emphasis of the values related to human integrity. The 'eastern' cultures promote the 'collective values' and during the early debates on the human rights subject, the representatives of Asian states expressed concerns about giving such stress to individuality and freedom. Singapore's long time Prime Minister Lee Kuan Yew justified that, wherever the 'western' countries try to protect the individuals from the oppressive state, 'the East' is trying to protect the state from the misbehaving individuals. ${ }^{19}$ However, the trends are to increase the emphasis on the 'western' notion of individual privacy mainly among the young people from Asia:

(...) insofar as there is an increasingly identical set of understandings and values surrounding notions of individual privacy in both East and West, then we may expect that a global informational and communication ethics will be able to develop a single, (quasi-) universal set of norms and practices for protecting that privacy. ${ }^{20}$

The 'western' cultures stress the importance of individuality and its expression. Although it is not a strict rule, traditionally, the individuality in a form of self-expression, creativity, freedom of choice, confidence, and consciousness enjoys more space and tolerance. This fact remains probably more apparent for the nations of Post-Soviet Bloc, whose history become inflicted by the leading idea of communism/ socialism. For more than a half century any traces of individuality were repressed and subjugated to a uniform

16 Hart (1953) 16.

17 Executive Board of American Anthropological Association (1947) 543.

18 Cohen (1985).

19 Haas (2008) 34.

20 Ess (2008) 187. 
frame of working class, whose public and private life have not been subject of any distinction. ${ }^{21}$ One regime, one political party, homogeneous set of beliefs in collective work, unified and prescript list of shared values - all that installed the package of rules, whereby the person did not even think about being different in any sense. ${ }^{22}$ Sexual orientation, for instance, has never been a point of one's consideration, while planning to live a relatively peaceful and quiet social life. Moral values have had a very limited scope of variations and have not been a subject of any changes or turns. The expression of own thoughts and opinion has been an undesirable feature of human existence leading to establishment of mechanisms of control. The social control of such intensity that any statement of criticism voiced in front of public audience, even neighbours, friends or family, led to a procedure of investigation, spying, and surveillance of disturber and their closest. In the worst case, such behaviour results in social isolation in prison or through the forced labour abroad. Hence, after the fall of the 'Iron Curtain', the aspects of life related to privacy gained a different status. The legislations of most of the post-communist countries are almost unified with those of the developed world. However, the understanding and perception of people related to the invasion to integrity, to individuality and consequently the interference to private life has still a largely diminished threshold of feelings.

Secondly, there are subjective factors that have a major impact on the private life, and the way the person perceives their privacy. These are generally the human curiosity, the attention, the individual expectations, or the personal sensibility or vulnerability. In addition, the privacy as a moral value derives from a personal preferences and desires. ${ }^{23}$ The whole human existence is subject of judgements and attention: the character, morals, lifestyle, or even the way of building own house and garden attract the attention of others. Its intensity and level can be 'measured' on basis of own creativity, self-expression or the nonconformity with the majority of people around. For instance, what is interesting and different attracts the others and vice versa, the conforming, average, the same or boring, simply does not. It is a human nature to be interested, to be involved, especially in a matter of unknown field. The level of compliance with the social rules and customs, as an inverse correlation, determines the level of unwanted attention. With a constant regard to this fact, it is disputably possible for individual to regulate and to control their private life. Another subjective way to determine whether there is a private life free from informal control is the scale of the individual expectations and personal sensibility. ${ }^{24}$ They differ on the ground of the social life the child was born into, the education or the habits of the family. The environment surrounding the growing person has an impact on the way they see the privacy and its intrusions. ${ }^{25}$ The conception of privacy would be most likely different according to person with a big and small family, city or country origin, extrovert or introvert character, higher or lower financial conditions, longer or shorter educational background etc. The personal sensibility, the expectations, and habits are the factors influencing the subjective perception of privacy. The internal attitude towards the rules of society we live in, determine the degree of acceptance of our freedom, our privacy, but accordingly the acceptance of others. Consequently, their interest might be welcomed or received with defence of our own space.

${ }^{21}$ Ušiak and Lasicová (2016) 53-54.

22 Jáger (2019).

23 Moore (2010) 34.

24 See Post (2001) link 2.

25 Schoeman (1992) 14. 
Thirdly, whether there it is or there is not a private life out of reach of control disputably depends on the efficiency and strength of different kinds of surveillance. The ID cards, databases of personal information, criminal records check, the CCTV or other visual surveillance techniques and DNA databases establish the system of careful and strict control over the people's behaviour. Notwithstanding the fact, people let themselves control by their public activities on social networks. On the other hand, they must have limits, they must not be misused. All these monitoring tools of social control are explicit and official; they are backwards monitored, controlled, and audited by the other authorities and their use is governed by rule of law. Most importantly, in a case of the cross of tolerable threshold, there is the way to protect the private life; the system also provides the remedy. Another cluster of surveillance technique is implicit and not controlled by anyone. It is dependent on one's ability to protect the personal space, opinions, freedom, integrity against the most efficient surveillance technique- the social influence and the pressure to conform. The private life should be the mirror of the internal world of person, the reflection of individuality, which tends to be similarly jeopardized on the everyday basis. The circumvention of surveillance with an emotional and personal subtext is often more challenging than the CCTV on the mast. The rules governing this kind of surveillance are not given and similarly not enforceable by the national or international authority but are regulated within our own capacity. A caring mother-in-law delving into private closet is simply not a subject of an individual petition to the UN Human Rights Council. There are parts of life, in which the borders are subject to our private consideration and attitude. The private life from this perception would be deliberated from forms of social control to the extent we make it deliberated.

The informal social control in its various forms arguably represents the higher threat to privacy. It is indirect, close and supervising the real everyday 'being' of people. Here, the individual faces the intrusions based on the very personal grounds that may vary in terms of internal attitude and consideration of external circumstances. The pressure of the environment that is capable to modify relationships and influent the emotional part of human existence may be stronger than any other form of social control. Whether there is a right to private life or privacy, whether some act represents the abuse and the consequent ways of protection depends on the subjective judgement. Only the personal decision puts the limits to the others and defends what belongs to intimacy and privacy. However, what is often more challenging, exhausting and nevertheless confusing, is the enforcement of such judgement.

\section{CONCLUSIONS}

Finally, a concept of 'private life' enjoys the protection under the number of international, regional, national rules, conventions, declarations or constitutions. They declare the recognition and guarantees of parts of life that belong solely to the individual, to their intimacy and privacy. Any unlawful interference to informational, bodily, territorial, communicational, or other private spheres is a subject of sanction. The international and national jurisdictions confirmed, and through the ruling specified, what represents such interference and consequently the possibilities to reach the appropriate remedy. Formally, there is a 'private life' out of social or political control. The states are bound to provide the citizens with the security of own privacy in terms of their domestic legal norms. Judicial power enforces such provisions and the international political authorities as well as nongovernmental organisations monitor their execution. This international executive system 
suggests the additional mechanisms available for individual complaints. Indeed, people have a right to defend their privacy and their own space from the unlawful interventions. On the other hand, there is an informal control, the attention of society, the pressure to conform, and the personal, real and virtual interactions on daily basis. The perception of a privacy and consequent vulnerability of every human being differ according to the environment and society they were accustomed to. The technical innovations rise concerns of one's privacy. Even though the legal rules all over the world aim to unify the criteria restricting the private life, the culture and traditions reflect the individual tolerance of interventions to privacy differently. Whether there is a private life free from social control in terms of the informal one remains uncertain. The mechanisms of non-technical surveillance, the attention and interest of public might represent even worse abuses of our right to privacy. There is a thin, subjective line between such infringement and the care of the closest, ordinary curiousness and other characteristics of human nature. It is most likely left upon the personal consideration and decision to keep the borders and to honour the private life of self and of the others.

\section{LITERATURE}

Cohen, Stanley, Visions of Social Control: crime, punishment, and classification (Polity Press 1985). Ess, Charles, 'East-West Perspectives on Privacy, Ethical Pluralism and Global Information Ethics' in Hrachovec Herbert and Pichler Alois (eds.), Philosophy of the Information Society (Vol. 7 Ontos Verlag 2008) 185-205.

Goda, Samuel and Ušiak, Jaroslav, 'What is the threat perception of the Slovak Republic?' (2016) 1 Central European Journal of International and Security Studies 61-87.

Haas, Michael, International Human Rights (Routledge 2008).

Hart, Herbert Lionel Adolphus, 'Definition and Theory in Jurisprudence' An Inaugural Lecture Delivered Before Oxford University on 30 May 1953 (Clarendon Press 1953).

Haule, R. Romuald, 'Some Reflections on the Foundation of Human Rights - Are Human Rights an Alternative to Moral Values?' (2006) 10 Max Planck Y. B. U. N. L. 367-95.

Jáger, Róbert, 'Vzt’ah vládnej moci a cirkvi na Vel'kej Morave.' (2019) 54 (1) Slavica Slovaca 3-10.

Johnson, Paul, 'The Enforcement of Morality: Law, Policing and Sexuality in New South Wales '(2010) 3 Australian and New Zealand Journal of Criminology 399-422.

Júda, Vieroslav, 'Prípustnost' kritiky sudcov' in Júda, Vieroslav and Šoltýs, Dominik (eds.) Nové horizonty v práve 2018 (Belianum Banská Bystrica 2018) 86-107.

Moore, D. Adam, Privacy Laws: moral and legal foundations (Pennsylvania State UP 2010).

Schoeman, Ferdinand David, Privacy and social freedom (CUP 1992).

Steiner, J. Henry and others, International Human Rights in Context: Law, Politics and Morals (OUP 2007).

Taylor, Nick, 'State Surveillance and the Right to Privacy' (2008) 1 Surveillance \& Society 72. Exec. Comm., American Anthropological Association 'Statement on Human Rights' (1947) 49 Am. Anthropologist 539-43.

Ušiak, Jaroslav and Lasicová, Jana, 'Identities of central European states in terms of formation of security environment.' (2016) 1 Annual of Language and Politics and Politics of Identity 45-59.

Warren, Samuel and Brandeis, Louis Dembitz, 'The Right to Privacy' (1890) 4 Harvard Law Review 193-220.

\section{LAWS}

African Charter on Human and Peoples' Rights (adopted 27 June 1981, entered into force 21 October 1986) (1982) 21 ILM 58 (African Charter)

American Convention on Human Rights "Pact of San José, Costa Rica", OAS adopted on 22 November 1969, entered into force 27 August 1979) 1144 UNTS 123 
American Declaration of the Rights and Duties of Man, OAS Res XXX adopted by the Ninth International Conference of American States (1948) reprinted in Basic Documents Pertaining to Human Rights in the InterAmerican System OEA/Ser L V/II.82 Doc 6 Rev 1 at 17 (1992)

Cairo Declaration on Human Rights in Islam adopted at the Nineteenth Islamic Conference of Foreign Ministers, 31 July to 5 August 1990 (CDHRI)

Charter of Fundamental Rights of the European Union (adopted 7 December 2000, 2000/C 364/01)

Convention against Torture and Other Cruel, Inhuman or Degrading Treatment (adopted 10 December 1984, entered into force 26 June 1987) 1465 UNTS 85 (CAT).

Convention for the Protection of Human Rights and Fundamental Freedoms (European Convention on Human Rights, as amended by Protocols Nos. 11 and 14) (ECHR)

Convention on the Elimination of All Forms of Discrimination against Women (adopted 18 December 1979, entered into force on 3 September 1981) 1249 UNTS 13 (CEDAW)

Convention on the Rights of the Child (adopted 20 November 1989, entered into force 2 September 1990) 1577 UNTS 3 (CRC)

Equality Act 2010

EU General Data Protection Regulation (GDPR): Regulation (EU) 2016/679 of the European Parliament and of the Council of 27 April 2016 on the protection of natural persons with regard to the processing of personal data and on the free movement of such data, and repealing Directive 95/46/EC (General Data Protection Regulation), OJ 2016 L 119/1

Human Rights Act 1998

International Convention on the Elimination of All Forms of Racial Discrimination (adopted on 21 December 1965, entered into force 4 January 1969) 660 UNTS 195 (ICERD)

International Convention on the Protection of the Rights of All Migrant Workers and Members of Their Families (adopted 18 December 1990, entered into force 1 July 2003) 2220 UNTS 3 Doc. $\mathrm{A} / \mathrm{RES} / 45 / 158$ (ICPR)

International Convention on the Rights of Persons with Disabilities (adopted 13 December 2006, entered into force 3 May 2008) 2515 UNTS 3 Doc. A/RES/61/106 (CRPD)

International Covenant on Civil and Political Rights (adopted 16 December 1966, entered into force 23 March 1976) 999 UNTS 171 (ICCPR)

International Covenant on Economic, Social and Cultural Rights (adopted 16 December 1966 and entered into force 3 January 1976) 993 UNTS 3 (ICESC)

Regulation of Investigatory Powers Act 2000

Universal Declaration of Human Rights (adopted 10 December 1948 UNGA Res 217 A(III)

Vienna Declaration and program of Action (adopted 25 June 1993 A/CONF 157/23)

\section{CASES}

Amman $v$ Switzerland (2000) 30 EHRR

Cyprus v Turkey [GC], no. 25781/94 ECHR 2001

Niemietz v Germany (1992)16 EHRR

$S$ and Marper $v$ The United Kingdom [2008] ECHR 1581

Slivenko v Latvia (2003) 48321/99

Smith and Grady $v$ United Kingdom (1999) 29 EHRR 493

$X v$ United Kingdom (App. No. 5877/72)

\section{LINKS}

1. DeCew, Judith Wagner, 'Privacy' in Edward N. Zalta (ed.) The Stanford Encyclopaedia of Philosophy $(2008)<$ http://plato.stanford.edu/entries/privacy/> accessed 1 May 2019.

2. Post, C. Robert, 'Three Concepts of Privacy' (2001) Faculty Scholarship Series Paper $185<\mathrm{http} / /$ digitalcommons.law.yale.edu/cgi/viewcontent.cgi?article=1184\&context=fss_papers\&sei-redir $=1$ \#search="private+life+privacy+free+from+forms+of+social+control"> accessed 21 May 2019. 